\title{
Przyjechali. Radosław Kobierski i jego Ziemia Nod: o miejscu tych, którzy błądzą
}

\section{They came. Radosław Kobierski and his Earth Nod: about the place of those who wander}

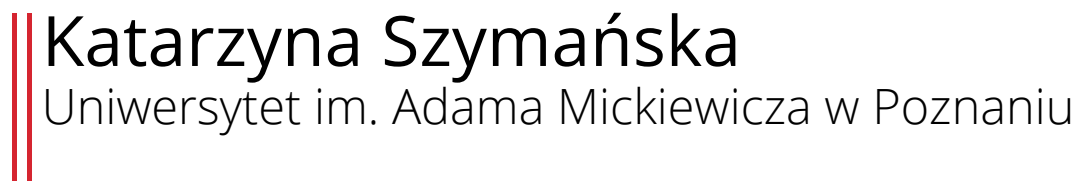

\begin{abstract}
The text is an attempt, to take a look into novel entitled Ziemia Nod by Radosław Kobierski from the perspective of those characters, who wander. Exile is not only a forced and temporary place trade, but also a constantly renewing inner state of characters, who have different nationality, status and age. The essence of the title land is created with different and overlapping experiences of an exile, emigration and displacements.
\end{abstract}

Key words: Radosław Kobierski, Ziemia Nod, wandering, resettlement

Streszczenie: Tekst jest próbą przyjrzenia się powieści Ziemia Nod Radosława Kobierskiego z perspektywy tych bohaterów, którzy błądzą. Wygnanie nie jest w niej jedynie przymusową i przejściową zmianą miejsca, ale też nieustannie odnawiającym się stanem wewnętrznym bohaterów różnej narodowości, pozycji społecznej i wieku. Istotę tytułowej krainy tworzą kolejne, nakładające się na siebie doświadczenia tułaczki, emigracji i wysiedlenia.

Słowa kluczowe: Radosław Kobierski, Ziemia Nod, błądzenie, wysiedlenie

W powieści Radosława Kobierskiego błądzenie zaczyna się od pierwszych stron utworu i jest przy tym błądzeniem samotnym. Tytułowa ziemia Nod to ziemia niestałości, miejsce wędrowców z bagażem cięższym niż zwyczajny tobołek podróżnika. Chociaż niewiele jest w nim przedmiotów, bohaterowie noszą ze sobą wspomnienia pierwszych miłości, domowych konfliktów, często biedy i doświadczania przemocy, a później wojennych tragedii, utraty najbliższych oraz pamięci - lub mimowolnej niepamięci o nich. Są też dzieci ukrywane w walizkach oraz pamiątkowe przedmioty, które czasami muszą zostać wymienione w pośpiechu na coś, co pozwoli przetrwać, jak skrzypce jednego z bohaterów, Michała Ciuronia, cygańskiego kapelmistrza, oddane $\mathrm{w}$ zamian za możliwość przeprawy przez Wisłę. „Ci, którzy wyjeżdżają, chcą uciec od miejsca, ale nie rozumieją, że 
tam zabiorą to wszystko, przed czym uciekają. W rzeczy samej zabierają w tę daleką podróż tylko jeden bagaż - strach"1.

Akcja Ziemi Nod rozpoczyna się 20 lat przed wybuchem II wojny światowej, a kończy w roku 1952. Wielkie wydarzenia XX wieku odbijają się w licznych małych historiach poszczególnych bohaterów, z których każda ma swój własny rytm i zakończenie. Łączy je jednak tytułowe hebrajskie nod $^{2}$, oznaczające błądzenie lub wędrowanie, które odnosi się w powieści zarówno do konkretnych losów uchodźczych - opisanych lub jedynie zasygnalizowanych w kilku zdaniach - jak i szerzej pojmowanej kondycji ludzkiej.

Zmagania z pamięcią, towarzyszące bohaterom utworu Kobierskiego, dają się odczuć także czytelnikowi. Podobnie bowiem w trakcie lektury powieści - liczącej sześćset stron, a przy tym odznaczającej się wyraźną fragmentarycznością - umykają niektóre sceny, postaci, miejsca. Szczegółowość jednych wątków, losów mieszczących się w zakreślonym przez pisarza przedziale czasowym, towarzyszy lapidarności innych. Czytelnik natrafia też często na nagłe przerwania mikroopowieści - zbudowanych wokół jednego lub kilku bohaterów - kolejnymi historiami. Niektóre z nich pozostają w pamięci na dłużej, inne natomiast rozmywają się wraz z upływem czasu przedstawionego i czasu lektury.

Powieść, obejmująca ponad trzydzieści lat, kończy się, gdy jedni jej bohaterowie - mimo, być może pozornego, myślowego oddalenia - przemierzają ziemię Nod, dotykając jej stopami, a drudzy (nie)obecni są tam jako widma, wspomnienia, powtórzone cechy w rysach twarzy innych już, żyjących osób. Podczas zmysłowego tanga Józka i Lilki Obrzutówny, osiemnastoletni Borowicz widzi w partnerce żydowską dziewczynkę, Dunię, z którą łączyła go dziecięca miłość. Złudzenie to jest tak silne, że Józek ma wrażenie, jakby w Lilkę wstąpił dybuk tej, która kiedyś „podarowała mu na urodziny ciastko z rodzynkami i miękki pocałunek" (ZN, 40). Rodzina Duni nie zdążyła na dłużej osiedlić się w Istowie, wsi położonej osiem kilometrów od Tarnowa. Sprowadził ją z Radomyśla, w 1850 roku, Mojsze, pradziadek dziewczynki o ciemnych oczach i długim warkoczu. W odpowiedzi na słowa Daniły - które przytaczam w dalszej części artykułu - iż historia ludzkości jest historią błądzenia, w której być może chodzi o to samo, co w opowieści o Kainie i Ablu - o odrzucenie, Józio pyta, czy Dunia jest winna i może ponosić karę za to, co stało się tysiące lat temu, a Daniło odpowiada mu: „- Nie, Józiu, nie może (...). - Jeśli jest, to i my wszyscy też jesteśmy

\footnotetext{
${ }^{1}$ Kobierski Radosław, 2010, Ziemia Nod, Warszawa, s. 533. Dalej stosuję skrót ZN i numer strony, bezpośrednio po cytacie.

${ }_{2}^{2}$ Biblijna Erec Nod, ziemia Nod pojawia się w Księdze Rodzaju, w historii Kaina i Abla. Bóg zwraca się do Kaina - który zabił swego brata - tymi słowami: „Bądź więc teraz przeklęty na tej roli, która rozwarła swą paszczę, aby wchłonąć krew brata twego, przelaną przez ciebie. Gdy rolę tę będziesz uprawiał, nie da ci już ona więcej plonu. Tułaczem i zbiegiem będziesz na ziemi!» Kain rzekł do Pana: «Zbyt wielka jest kara moja, abym mógł ją znieść. Skoro mnie teraz wypędzasz z tej roli, i mam się ukrywać przed tobą, i być tułaczem i zbiegiem na ziemi, każdy, kto mnie spotka, będzie mógł mnie zabić!» Ale Pan mu powiedział: «O, nie! Ktokolwiek by zabił Kaina, siedmiokrotną pomstę poniesie!» Dał też Pan znamię Kainowi, aby go nie zabił, ktokolwiek go spotka. Po czym Kain odszedł od Pana i zamieszkał w kraju Nod, na wschód od Edenu" (Rdz 4, 11-16).
} 
winni" (ZN, 235). Biblijny kontekst pozwala odczytywać uchodźcze historie bohaterów powieści Radosława Kobierskiego w szerszym, uniwersalnym wymiarze. Na taką możliwość wskazują też pierwsze i ostanie sceny utworu oraz chrystusowy wiek Jeszui noszącego hebrajskie imię Mesjasza ${ }^{3}$. Opowieść ta formalnie domknięta jest wyrazistą, przez swoją symbolikę, ale i nienachalną klamrą kompozycyjną, którą stanowi zarówno okres trzydziestu trzech lat życia bohatera, jego cielesne naznaczenie przez obrzezanie, a później chorobę, jak i rozpaczliwy krzyk dziecka - na początku powieści małego Jeszui, a w ostatnich akapitach nowo narodzonego dziecka Olgi, córki Borowiczów, która nie zgodziła się na aborcję mimo zagrożenia własnego życia i zmarła przy porodzie. Historia Ziemi Nod mogłaby znaleźć jednak swoje przedłużenie w spojrzeniu zza okna tarnowskiego tramwaju (pamiętając o jego historii w tym mieście ${ }^{4}$ ) czy autobusu, spojrzeniu należącym do kolejnego błądzącego.

Współistnienie dwóch historii i dwóch przestrzeni - aktualnej i minionej - obecne jest także w teledysku do piosenki Radiohead I Promise ${ }^{5}$, wyreżyserowanym przez Michała Marczaka ${ }^{6}$, w którym oczami fantomowego pasażera autobusu ikarus oglądamy Warszawę po zmroku. Pojazd mija między innymi jedną z jej mieszkanek (graną przez Agatę Buzek), a także ścianę z napisem „Tęsknię za Tobą, Żydzie”, będącym częścią projektu Rafała Betlejewskiego. Opustoszały nocny autobus wypełniają głównie przebłyski świateł, pojawiające się dzięki dużej oszklonej powierzchni. Efekt ten towarzyszy innym właściwościom szyby zdolnej zarówno odsłaniać przestrzeń, która jest za nią (w pustym ikarusie po obu stronach), jak i odbijać tę, w której znajduje się obserwator. Ma on w sobie coś z uchodźcy, tułacza - zamieszkującego co prawda inne czasy niż Żyd, którego przywołuje napis Betlejewskiego, lub jeden z tych, obecnych w powieści Kobierskiego, lecz podobnie niepasującego. Podobnie również bliskiego, bo przecież każdy czasami bywa uchodźcą, choćby duchowym, i bywa w miejscach, które są jeszcze bardziej „nie moje własne” niż wszystkie inne.

O nakładających się na siebie obrazach z różnych planów i porządków tak pisze Kobierski w jednym z wierszy z tomu Drugie ja, wydanym rok po ukazaniu się Ziemi Nod:

\footnotetext{
${ }^{3}$ Kontekst biblijny w powieści Kobierskiego pozwala wydobyć duchowy wymiar bycia w drodze, tułaczkę wewnętrzną związaną z kondycją człowieka. Jednocześnie jednak daje możliwość polemiki z przekonaniem o przeznaczeniu narodu żydowskiego, nałożonym na Jeszuę podwójnie - przez obrzezanie i imię, które w języku hebrajskim mieści w sobie słowo „zbawi”.

${ }^{4}$ W Tarnowie od roku 1911 kursował elektryczny tramwaj. Trakcję zlikwidowały okupacyjne władze niemieckie w 1942 roku, przeszkadzała ona bowiem w przemieszczaniu się wojsk na wschód. Radosław Kobierski kilkukrotnie wspomina w swojej powieści o tarnowskim tramwaju. Pisze na przykład: „Minął właśnie zatopiony w słońcu plac Kościuszki, na którym utknął tramwaj jadący na Wałową. Ludzie wysiadali, złorzecząc, ale i tak byli dumni z tego deficytowego taboru" (ZN, 55). Jedna z bohaterek, wywieziona na roboty do fabryki amunicji w Lipsku, swój list do najbliższych kończy słowami: „PS Chciałabym - wiem, jakie to głupie, jeszcze raz wsiąść do tramwaju i pojechać ulica Krakowska...” (ZN, 401).

${ }^{5}$ Utwór pochodzi z albumu Ok Computer Oknotok 1997 2017, który stanowi specjalną - uzupełnioną o trzy niepublikowane dotąd w wersji studyjnej piosenki - edycję słynnego albumu sprzed 20 lat.

6 Reżyser filmów Kobieta poszukiwana (2009), Koniec Rosji (2010), Fuck the Forest (2012), Wszystkie nieprzespane noce (2016), a także m.in. teledysku do piosenki Beautiful People (2016) Marka Pritcharda z udziałem Thoma Yorke’a.
} 
Za szybą, na której nakładają się warstwy,

Szklisty laserunek, ten i tamten świat,

Coraz zimniejszy, miasta jak mgławice,

Coraz bardziej samotne, oddalone od siebie.

Za szybą autobusu, który też w końcu

Wypali się i ostygnie jak biały karzeł,

Po czym wypatruje w najbliższej czarnej

Dziurze (sklep, entropia, bar tylko jeden).

(Kobierski 2011, 31)

Istotą świata $\mathrm{w}$ przytoczonym wierszu jest wielokrotność - warstwy obrazów, nakładające się na siebie barwy, stopniowalność tonów, nieskończona liczba wszechświatów, liczenie gwiazd. Chociaż nie zawsze jest w tej własności utworu matematyczna regularność, to w jego świecie nie ma niezapełnionych przestrzeni i zniknięć, które nie zostawiają po sobie żadnego śladu. Po przywołaniu postaci Henrietty Swan Leavitt, badaczki gwiazd zmiennych, podmiot Kobierskiego mówi:

Urzekło mnie zwłaszcza to: „Im wolniej

Pulsują cefeidy, tym stają się jaśniejsze”.

A podobno wszystko to tętni w rytmie serca.

Za szybą, za którą ciągle wzrasta nieporządek.

Tam i tu. Filiżanka może rozpaść się

Na tysiące kawałków, ale sama się nie poskłada.

Możesz mnie skleić, zapukać we mnie.

Ale wtedy, musisz to wiedzieć,

Chaos wzrośnie w innym miejscu.

(Kobierski 2011, 31)

Końcowy fragment Ziemi Nod zawiera natomiast słowa: „Nie ma pustych miejsc, pomyślał Jeszua. Życie popychane jakąś niewyobrażalną siłą, pod ogromnym ciśnieniem, wypełnia wszystko, każdą sferę przestrzeni" (ZN, 603). Podobne przekonanie wyraża wcześniej Daniło, mówiąc:

ludzkie życie samo w sobie jest niczym, samo z siebie nic nie może. Zawsze odnosi się do innego życia i w nim odnajduje spełnienie. Ludzkie istnienia przypominają sieć, jedno jest powiązane $\mathrm{z}$ drugim, jedno zależne od drugiego. Nie ma tu miejsca na przypadek. Człowiek oczywiście może się buntować przeciwko temu porządkowi, może próbować świadomie wykluczyć się z systemu, ale nawet ten ruch jest przewidziany, niejako wpisany w ekonomię życia (ZN, 255).

Powieść Kobierskiego rozpoczyna się od znaku na ciele nowo narodzonego, a kończy pochyloną postawą 33-letniego Jeszui, którą powodował między innymi bolesny guz powstały na karku po uderzeniu bykowcem w obozie w Płaszowie. Jego ojciec, mówiąc o dokonaniu brit, czyli rytuału obrzezania, zaznacza, że od tego dnia chłopiec „miał być określony przez to, czego już nie posiadał, na owym braku budować miał swoją tożsamość. Właśnie dzięki niepełnej cielesności miał się stać kimś w pełni fizycznie określonym, dzięki ograniczeniu - kimś absolutnie wolnym" (ZN, 12). Do niego dochodzi później cielesność z(a)łamana - właściwa krainie błądzenia - obciążona 
troskami i trudami przemierzanej drogi. Tytułowa nazwa pojawia się w powieści tylko raz, w przywołanych przez Annę słowach Jakuba:

Czy myślisz, że Kain nie doświadczył odrzucenia na długo przedtem, zanim On odrzucił jego ofiarę? Popatrz, wszystko jest już zawarte w imionach. Kain miał być zdobywcą, Hewel musiał umrzeć. Hewel został ofiarowany dla Seta, Kain zaś wypędzony na pustynię, gdzie błąka się z tą świętą literą na czole do dzisiejszego dnia. Od początku ludzkość karana była za działania sił, którym nie mogła sprostać. Życie, to prawdziwe życie, takie jakie znamy, to które stało się naszym udziałem, rodziło się na wygnaniu, w ziemi Nod, na pustyni Beer-Szeby. Jesteśmy kozłem Azazela, Anno. To on nas nauczył żyć, on zbudował miasta i fabryki, on nauczył nas nauki i sztuki. Musi być ucisk, musimy być smagani przez przeciwności, lekceważeni, pogardzani i odrzucani - to jest cena życia, którego sami sobie nie wybraliśmy (ZN, 384).

- „życia, które ktoś obliczył na śmiesznie krótki czas. Czym bowiem było kilkadziesiąt lat w stosunku do trwania Ziemi, a nawet do życia drzew?" (ZN, 544), jednak, jak rozmyśla dalej Borowicz, „skąd mógł wiedzieć, jak ten czas przeżywały inne istnienia? Może dwieście, trzysta lat dla dębu znaczyło dokładnie tyle, ile trzy tygodnie dla motyla?" (ZN, 544).

Biblijna ziemia Nod, w której zamieszkał Kain po zabiciu Abla, jest miejscem wygnania, braku opieki, miejscem bez Boga7 lub też bez jego stałej obecności, którą trzeba dopiero na nowo odnaleźć. Podobnie w utworze Kobierskiego, błądzenie jest zarówno stanem duchowym, umysłowym, jak i fizycznym przemieszczaniem się, które w utworze przyjmuje kilka form, przede wszystkim przesiedlenia, ucieczki i powrotu. Są one znakami historii, o której czytamy w powieści, że „jest w rękach szaleńców, którzy w wolnych chwilach, pomiędzy aperitifem a kolacją, przestawiają granice państw, wytyczają nowe szlaki handlowe, zmieniają koryta rzek, przerzucają mniejszości narodowe $\mathrm{z}$ miejsca na miejsce i w nigdy niegasnącym zdziwieniu przyglądają się efektom" (ZN, 19). Nie mniej tułacze - od opisów przymusowego opuszczenia miejsca zamieszkania - są ostatnie, powojenne fragmenty opowieści Kobierskiego. Bohaterowie nie czują się sobą, nie poznają (lub czynią to z trudem) swoich bliskich i znajomych, gubią cząstki własnej pamięci, próbują odtworzyć domowe życie rodzinne, lecz chwilę później tracą je przez nakaz aresztu lub nagłą śmierć. Jeden z bohaterów wyraża przekonanie o tym, iż ziemia, z której wymazano tak wiele istnień, miejsc, więzi, powinna sama zniknąć. Powraca także sprawa emigracji Żydów do Palestyny.

Jako pierwsza do tytułowej krainy błądzenia przyjeżdża młoda para z dzieckiem - Knapp, jego żona oraz syn Henryk, późniejszy nazistowski oprawca i jeden z głównych bohaterów powieści. Ich furmanka staje naprzeciw drugiej, jadącej w przeciwną stronę, w której siedzi młode żydowskie małżeństwo Ettingerów - Jakub i Anna. „Ettingerowie od razu poznali, że tamci jadą z daleka. Mówili bardzo twardo, z obcym akcentem” (ZN, 13).

${ }^{7}$ Podobnie określa swoje miejsce zamieszkania jedna z bohaterek powieści Kobierskiego: „«Bóg tę ziemię opuścił - mówiła Anna Ettinger do swoich córek, Elki i Hani. - Opuścił te ziemie wasz ojciec, a teraz i sam Bóg. Nic tu po nas»" (ZN, 72). 
Przyjechali ze Śląska, a na słowa Anny, wyrażające zdziwienie wobec motywacji ludzi do tak dalekich wędrówek i wyboru miejsca, do którego zmierzają, Jakub odpowiada: „- Czasem człowiek czuje taki zew (...) Nigdzie nie może znaleźć sobie miejsca. Musi być cały czas w drodze. I tylko czeka. Aż przestanie wiać albo umilknie zgiełk w jego duszy. Wtedy będzie wiedział, że je znalazł" (ZN, 14). Jak się niebawem okazało, pod wpływem widoku rozciągającego się wokół starej chałupy, którą wskazał przybyłym Jakub, Knapp zrozumiał, że właśnie tego miejsca szukał. Zdarza się jednak, iż to niejasne, lecz silne przeczucie odnalezienia domu jest mylące. U Knappa również nie trwało ono długo - zaczął pracować jako komiwojażer, a do domu przyjeżdżał jedynie na święta Bożego Narodzenia i na Wielkanoc, co odbijało się przede wszystkim na psychice młodego Henryka. „Po pewnym czasie Genowefa zrozumiała, że jej mąż się pomylił. Dalej szukał tego jedynego miejsca. Tyle że już sam. Bez nich. Teraz już była pewna, że nigdy tego miejsca nie odnajdzie i nigdy do nich nie wróci" (ZN, 91).

Przyjechał też Bieluń, zegarmistrz i mistyk - po Wielkiej Wojnie wyruszył z okolic Stanisławowa do Tarnowa, gdzie się osiedlił i ożenił. W więzieniu, w którym odsiadywał wyrok za zabójstwo w afekcie, spotkał Madeja - męża Czajki, który wcześniej upijał się do nieprzytomności w tarnowskich szynkach, a później bił swoją żonę oraz dzieci, Staszka i Henię - i wpłynął na jego przemianę. Nie trwa ona jednak długo, a los Madeja kończy się tragicznie.

Znaczna część powieści dotyczy losów rodziny Borowiczów - Pawła, Tosi i ich dzieci, a wśród nich Wojtka i Tadeusza, którzy przyjaźnią się ze Staszkiem Pasierbem, nad wyraz dojrzałym i poważnym, „jakby wiekiem umysłowym wyprzedzał swoje ciało o kilka dekad" (ZN, 85). Wojtek mówił, że Staszek „z innej gliny był ulepiony” (ZN, 85), jednak to właśnie ten „napływowy, emigrant z dalekiego Pomorza” (ZN, 85) uczył Tadeusza poznawać Tarnów, a także „rozbudzał w nim potrzebę kontaktu ze sztuką i jej rozumienia” (ZN, 85).

Jeszcze dalszą drogę przebył Daniło, którego wyjątkowe usposobienie oraz elementy kultury i tradycji prawosławnej, które przynosi ze sobą, czynią z niego postać wyjątkową, a jego barwną osobowość odzwierciedla atmosfera izby, w której mieszka. Znajdowały się w niej porozrzucane pędzle, pojemniki z farbami i miseczki pełne suchych pigmentów; jest między innymi biel ołowiowa, cynober, żółcienie, zielenie chromowe i ochry. W samotni Daniły, gdzie „wszystko było prostsze, pozbawione tego wszechobecnego ciężaru, jakby czas tu się wykoleił i został pominięty, czy też po prostu zapomniany przez główny nurt wydarzeń" (ZN, 234), znalazł swoją przystań Józio, jeden z trzech braci Borowiczów. Daniło

przyjechał tu w 1920 roku razem z ogromną rzeszą Ukraińców, którzy podążając za rządem atamana Petlury, uciekali przed kontrofensywą sowiecką. Władze ukraińskie niczym aresztantów wsadzono wtedy do pociągu w Stanisławowie i odesłano do Tarnowa. O bolszewikach, jak i zresztą o Polakach - chociaż szeptem, ze względu na sojusz i białych Denikina - opowiadano straszne rzeczy. Że były gwałty, 
chłosty, publiczne rozstrzeliwania i samosądy, biali wyrzynali robotników i Żydów, bo ci przechodzili na stronę rewolucji, czerwoni wyrzynali białych, a nawet mienszewików i eserowców, na wsiach zupełne bezprawie, nikt już nie może upilnować tego żywiołu. Ludzie uciekali na południe i na zachód, na Bukowinę i do Rumunii (ZN, 135-136).

W mieście zaczyna panować coraz większy chaos i ciasnota, „codziennie ulicami Grabówki od wschodu przybywali uchodźcy z Dębicy, Bełza, a nawet Lublina" (ZN, 239). Spokój zdaje się trwać najdłużej w izbie Daniły, a wyznacza go rytm pisania ikon. Przybliżając Józiowi technikę uzyskania wewnętrznego światła ikony, prawosławny mieszkaniec ziemi Nod mówi o nieustającym kole błądzenia:

- Na początku był chaos i ciemność - kontynuował Daniło. - Potem wyłoniło się światło. Święci pokonywali taką samą drogę. Ale to stwarzanie wcale nie dobiegło końca, wszystko jest w nieustannym ruchu, każda chwila z owych pierwszych siedmiu dni odtwarza się na nowo: niewinność, bunt, wygnanie, powrót, odrzucenie. Człowiek nieustannie błądzi. Czymże ta wojna różni się od historii Kaina i Abla? Czy w gruncie rzeczy nie chodzi w niej o to samo? O odrzucenie? (ZN, 235).

W powieści wielokrotnie pojawiają się subtelne znaki pozwalające wpisać losy bohaterów w wymiar uniwersalny. Precyzyjny opis miejsc ${ }^{8}$ i usytuowanie w konkretnym, znamiennym historycznie czasie nie przeszkadza w stawianiu najważniejszych pytań o istotę błądzenia czy pochodzenie zła. Pierwsze z nich jest także rozważaniem, czy „obcy” może stać się w pełni „swoim”, a jeśli nie - o czym świadczą losy Daniły - to czy jest coś, co kończy tułaczkę przesiedleńca lub emigranta. „- Przyszli już trzeci raz. Z komitetu. Wtedy chcieli, żebym podpisał kartę ukraińską. A jaki tam ze mnie Ukrainiec... Od dwudziestu lat tu żyję. Potem, że mam iść do likwidacji getta. Nie zgodziłem się, to chcą mnie zastraszyć” (ZN, 252).

Ziemia Nod jest dla Daniły i wielu innych osób o podobnych losach, krainą „pomiędzy” - już nie tą, z której się wyjechało, ale też nie nowym domem, który w równym stopniu dzieli się z wszystkimi jego mieszkańcami, bo nawet jeśli samemu będzie chciało się uczynić to miejsce domem, to inni przypomną, że nigdy nim ono nie będzie. Podobnie jak dla Cyganów, mimo iż „brali śluby, chrzcili swoje dzieci, razem z miejscowymi świętowali Boże Narodzenie i Wielkanoc...” (ZN, 364). Czytamy też, iż „od listopada czterdziestego piątego roku przez miasto przetoczyło się ponad sześćdziesiąt transportów z repatriantami ze wschodu. Tysiące osób. A zostawali tylko nieliczni” (ZN, 534). „Ludzie wracali nieraz z odległych stron, ze wschodu, południa, z ziemianek i obozów, z emigracji, wyglądali jak cienie, niczym własne powidoki, ale jednak żyli" (ZN, 535). Ich niepewne istnienie podawane będzie odtąd w wątpliwość, nie tylko przez znajomych i rodzinę

8 Tomasz Cieślak, w tekście zatytułowanym Geografia i topografia „Ziemi Nod” Radosława Kobierskiego, (2012), podkreśla ogromną pracę dokumentacyjną wykonaną przez autora przed napisaniem powieści, na którą składało się „poznawanie historycznych źródeł, a ponad wszystko: topografii miasta i geografii jego okolic, oraz rozmowy z mieszkańcami Tarnowa” („Białostockie Studia Literaturoznawcze", nr 3, s. 101). 
w pytaniu „Ty żyjesz?”, ale też przez nich samych. Takie było też życie, a zatem również śmierć tych, którzy nie chodzą już po ziemi Nod. „Byli i nie było ich zarazem. Zawieszeni gdzieś pomiędzy światami" (ZN, 535).

Błądzenie nie kończy się na słowie Aussiedlung, które wprowadzało powszechny strach o to, do jakiej grupy będzie się przyłączonym, strach odzwierciedlony w nerwowej wymianie stempli w kartach pracy - swastyki lub litery „K” - w których pokładano nadzieję, jakoby jeden z nich miał uchronić przed wysiedleniem. Wtedy było już za późno na ucieczkę, ale w czasie, gdy było to jeszcze możliwe, wierzono, że to dom zapewni bezpieczeństwo. Wielu przez długi czas nie dopuszczało do siebie możliwości katastrofy - „W gminie żydowskiej panował zupełny chaos. Ludzie nie wiedzieli: uciekać czy obchodzić szabas” (ZN, 216). „Rozporządzenia o gromadzeniu zapasów żywności” (ZN, 216) towarzyszą przygotowaniom „do uroczystej kolacji szabasowej dla wysiedleńców” (ZN, 216) oraz wieczoru pieśni religijnych na rzecz uchodźców z Niemiec. W domu Miry i Hewla Meerbaumów, rodziców chłopca, którego opisem obrzezania rozpoczyna się powieść Kobierskiego, trwa jednocześnie pakowanie najpotrzebniejszych rzeczy i rodzinnych pamiątek oraz szykowanie kolacji szabasowej. Być może każda zagłada „Zaczyna się całkiem niewinnie” (ZN, 63), jak ta, która ma swój początek „W ciszy i skupieniu wewnątrz spróchniałych pni, w opustoszałych norach lisów i starych oborach" (ZN, 63), jak opisuje Kobierski w preludium do nalotu szerszeni.

Nikt niczego się nie spodziewa, nikt nie słyszy tych fałszywych dźwięków. Tak mijają kolejne dni. Zwiadowcy przekazują w swoim ciemnym narzeczu informacje, współrzędne, burzą się i rwą sejmy, ale i tak pewnego dnia wszystkie zastępy ruszają zgodnie, w postaci ciemniejszego obłoku wzbijają się nad miasto i bezbłędnie trafiają do niczego się niespodziewającego ogrodu. Już na kilka chwil przed atakiem całe istnienie wstrzymuje oddech. Liście zastygają bez ruchu, soki przestają płynąć i głupieje chlorofil. Jest za późno na zwarcie szeregów. I pszczoły, i trzmiele, niestrudzeni pracownicy ugoru, bezwolnie poddają się klęsce, zmasowanemu atakowi, zbiorowemu mordowi, który nie ma żadnego celu, nie ma absolutnie sensu. Cały ranek i popołudnie trwa ta cicha masakra - w środku wielkiego miasta, pośród gwizdów lokomotyw, jazgotu tramwaju, wrzawy na stadionie miejskim. W końcu jeden z olbrzymich szerszeni daje znak do odwrotu. Wracają znów do swoich papierowych gniazd, nor i do omszałych pni. Ugór cichnie. (...) Po kilku godzinach, jakby nigdy nic, wracają ptaki. Drzewa, krzewy, kwiaty zakwitną następnej wiosny. Zapach nektaru znów zanęci pszczoły i osy. Zaprawdę bez nich ogród nie może istnieć (ZN, 63-64).

Opowieść ze świata owadziego jest kolejną, jeszcze drobniejszą mikrohistorią, która zdaje się być pozbawiona punktów wspólnych z wielkimi wydarzeniami, które pochłaniały wtedy Europę. Łączy je jednak wiele, podobnie jak dwie pozornie odległe od siebie krainy i dwa języki - Erec Nod i Terra nullius - w obu nie respektuje się bowiem prawa ludzi do życia w miejscu, które ci uważają za swój dom. Obie nazwy odnoszą się również do formy obecności lub pozornej nieobecności w przestrzeni człowieka określającego status obszaru, w którym nigdy nie jest się „u siebie”, a który 
jednocześnie nie byłby tym, czym jest, bez zamieszkujących je istnień, nawet tych widmowych czy fantomowych. Ziemia Nod nie istniałaby bez jej mieszkańców-na-chwilę, tych kilkudziesięciu opisanych w powieści, ale i pozostałych, których losy są niedopisane.

\section{Bibliografia}

Cieślak Tomasz, 2012, Geografia i topografia „Ziemi Nod” Radosława Kobierskiego, „Białostockie Studia Literaturoznawcze”, nr 3, s. 97-108.

Henseler Daniel, 2013, Podróż, obcość, powrót do domu: conditio podmiotu lirycznego w wierszach Adama Zagajewskiego, w: Poetyka migracji. Doświadczenie granic w literaturze polskiej przełomu XX $i$ XXI wieku, Czapliński P., Makarska R., Tomczok M. (red.), Katowice, s. 368-384.

Kobierski Radosław, 2011, Drugie ja, Poznań.

Kobierski Radosław, 2010, Ziemia Nod, Warszawa.

Lindqvist Sven, 2016, Terra nullius, w: Podbój, Kowadło-Przedmojska I., Haykowska M. (przeł.), Warszawa, s. 193-359.

Nęcka Agnieszka, 2011, Błądzić jest rzeczq ludzka, „Nowe Książki”, nr 1, s. 48-49.

Nowacki Dariusz, 2010, „Ziemia Nod” Radosław Kobierski, „Gazeta Wyborcza”, 16.11.

Pismo Święte Starego i Nowego Testamentu, 1980, w przekładzie z języków oryginalnych, oprac. zespół biblistów polskich z inicjatywy benedyktynów tynieckich, wyd. 3. popraw., Poznań-Warszawa.

Wajs Joanna, 2010, Mapa (końca) świata. O „Ziemi Nod” Radosława Kobierskiego, „Cwiszn”, nr 4, s. 114.

\section{O Autorce:}

Katarzyna Szymańska - absolwentka filologii słowiańskiej i filologii polskiej na Uniwersytecie im. Adama Mickiewicza w Poznaniu, obecnie doktorantka w Zakładzie Badań nad Tradycją Europejską na Wydziale Filologii Polskiej i Klasycznej UAM. Zajmuje się przede wszystkim twórczością Thomasa Bernharda i innych pisarzy niemieckojęzycznych. Interesuje się także polską poezją współczesną, literaturą żydowską oraz nieantropocentrycznymi miejscami w prozie i poezji. Współpracuje z Kołem Naukowym Miłośników Kultury i Literatury Żydowskiej „Dabru emet”, działającym na poznańskiej polonistyce. 
